\title{
Structural Change in East Asia: Is Hegemonic Stability Theory still relevant?
}

\author{
Asih Purwanti ${ }^{1}$ \\ ${ }^{1}$ National Sun Yat-sen University, Taiwan, and Universitas Brawijaya, Indonesia \\ 1.asihpurwanti@gmail.com
}

\begin{abstract}
East Asia today as a region can be argued to have a structural change happens today. During the Cold War time, people believed that the U.S. and Japan are acting as a hegemonic power served in the region. But today, people may see several important phenomena occurred in the region: (1) the rising power of the PRC both in economy and military in the region, (2) the growing threat from the North Korea, (3) the decline economy strength of Japan, (4) the reluctant U.S. under Trump administration towards East Asia's intra-region problem. These conditions had left both South Korea and Taiwan at the most vulnerable position. Therefore it is easy to argue that there is a structural change occurs in East Asia region. But using Hegemonic Stability Theory as a lens, I argue that there are no structural changes in East Asia. It can be argued that although Trump is trying to convince the world that the U.S. will be no longer to serve as a hegemon in the world, the U.S. is still serving as a leader in East Asia. Japan is also still having their economic power as the major power in the region. South Korea and Taiwan are maintaining their traditional relations with the U.S. and Japan. And for the PRC, although its growing economic and military power is clear, but PRC is not acting as a hegemon who sacrifice their attributes to serve as a leader in the region. At last, even though North Korea is now acting unexpectedly with their nuclear weapons, East Asia region remains stable because the U.S. still performs as one hegemonic actor who is willing to maintain the stable relations among actors in the region.
\end{abstract}

Keywords: Hegemonic Stability Theory, East Asia, structural change

\section{INTRODUCTION}

International relations according to Hegemonic Stability Theory (HST) is a structural system. Relationship among states as the actors shaped a system and the system shaped the behaviour among those actors. Although there are no hierarchical manners in the relationship among states, the international system somewhat remains stable because of the structure in international sphere where one or two states are willing to be the leader among others. In this situation, the proponents of HST argues that when the international system changes, so will the incentives and behaviour among actors. So it is the 'structure' which is determined by a hegemonic major power who will be the main influencer on the international system. And whenever the structural scheme is changed, it will definitely change the international system. The above powerful argument made HST to be one of strongest theory to explain the behaviour of states in international relations.

This paper aims to look at whether HST is still relevant to study the actors' behaviour in International Relations. East Asia today can be argued as one dynamic region in the world because of the composition of the actors and the structure of power in the region. We cannot ignore the fact that the agenda of the world politics today must have words such as China, 
North Korea, the US, nuclear weapons, and security. I want to look at how HST can be one good tool to explain the dynamic in East Asia. First, I present how HST explains the world works. How this perspective has a strong position in International Relations. Second, I compare HST to other perspectives, the Defensive and Offensive Realism in analyzing actors' behaviour in International Relations. Third, how HST explain the interactions among actors in East Asia.

\section{RESEARCH METHOD}

This research is using literature review method with a purpose to dicuss the theoretical debate on the case selection. According to Snyder, literature review is a relevant method for researchers who want to engange in evaluating theory or to examine the validity or accuaracy of a certain theory or competing theories.[1]

\section{RESULTS AND DISCUSSION}

My work will be quite similar to Tony Tai-Ting Liu's paper in 2011 as they also support that HST is still applicable in explaining international politics in East Asia. However, Liu presents their argument in the context of transformations brought by globalization and focus in world' realm that the US has declined and China has arisen. Following Samuel Kim's words (2004): "With the Korean peninsula as its strategic pivot, it is the one and only international region or subregion where the world's four major powers - China, Japan, Russia and the US - uneasily meet and interact and where their respective interests coalesce, compete, or clash in a situation-specific way"[2]

The hegemonic stability argues that whenever a world order dominated by a single power (hegemony) will be most stable order and will have the most open economic order among actors. HST's argument is based on Charles Kindelberger proposition that is an open and liberal world economy requires the existence of a hegemonic and dominant power. It is further held that greater aggregate wealth will be produced under such a world order.[3] According to Kindleberger, "a liberal economic order needs leadership, a country which is prepared, consciously or unconsciously, under some system of rules it has internationalized, to set standards of conduct for other countries; and to seek to get others to follow them...". [3] Robert Gilpin suggests that "a liberal international economy can only be formed and maintained through the support of the most powerful state or states in the system".[4]

Keohane mentions that Underlying this statement is one of the two central propositions of the theory of hegemonic stability: 1) that order in world politics is typically created by a single dominant power. Since regimes constitute elements of an international order, this implies that the formation of international regimes normally depends on hegemony. 2) The other major tenet of the theory of hegemonic stability is that the maintenance of order requires continued hegemony.[5] Emphasizing on Kindleberger words, "for the world economy to be stabilized, there has to be a stabilizer, one stabilizer".[3] This implies that cooperation, which we define in the next chapter as mutual adjustment of state policies to one another, also depends on the perpetuation of hegemony.[5]

To some extent, it is easy to categorize HST as a variant theory of international politics, this is because of their arguments that it is the attributes of the system which will affect the actors' behaviour. However, Keohane rejects the idea that a deterministic version of the theory of hegemonic stability, relying only on the Realist concepts of interest and power is indeed incorrect.[5] As Keohane notes, "There is some validity in a modest version of the first 
proposition of the theory of hegemonic stability - that hegemony can facilitate a certain type of cooperation-but there is little reason to believe that hegemony is either a necessary or a sufficient condition for the emergence of cooperative relationships. Furthermore, and even more important for the argument presented here, the second major proposition of the theory is erroneous: cooperation does not necessarily require the existence of a hegemonic leader after international regimes have been established. Post-hegemonic cooperation is also possible". [5]

Therefore according to HST, an international cooperation will be well developed whenever one hegemonic power is present. The hegemonic power will be the only actor who is able to sacrifice itself to maintain the cooperation among states in the world. HST also suggests that a stable cooperation will only happen in a liberal society which will lead to a free market international economy where there will be openness and non-discrimination. For a hegemon, it is important to be able to maintain its role as a leader in the system, the hegemon should be committed to the values of liberalism or its social purpose and domestic distribution of power must be favorably disposed toward a liberal international order. For HST, cooperations most likely will develop in the economic area, but the leader should provide also a condition of military security to ensure the development of a free-market international cooperation.

Webb and Krasner offer an empirical assessment on HST particularly in explaining the situation of international economic system. Webb and Krasner suggest that "HST is the most prominent approach among American political scientists for explaining patterns of economic relations among the advanced capitalist countries since 1945".[6] Similar to Kindleberger and Gilpin, Krasner is also strongly agree that the distribution of power among the states is the main root of the competitions among actor in international economy. And the presence of one hegemonic power is necessary to keep the international system remains stable. [6]

Meanwhile, defensive realism sees that cooperation as a tool to survive within the anarchical world. Therefore defensive realist like Stephen M Walt suggests that states in order to survive, states need to cooperate in the form of alliance. Walt suggests that in an anarchy situation, states form alliances to protect themselves.[7] This behavior is influenced by a perception of threats, the state eventually will be likely to choose to create an alliance with other actors to balance the hegemonic power. The perceptions of the threat and the intentions of other actors determine the one state's action. Defensive realists suggest that the policy makers should make policies that deescalate the threats. Cooperation, according to defensive realism, will be most likely to occur in the area of economic and security where foreign aid will be closely related to the alliance formation. Foreign aid will be important in a balancing behaviour because aid is usually a manifestation of political alignment, not a cause of alignment. So according to defensive realism, security cooperation will be conducted prior to the economic cooperation.[7]

In contrast to defensive realism, offensive realism departs from a view that the anarchical structure of an international system is defined by major powers. To offensive structural realists like John Mearsheimer, states likely try to be the hegemon in the system. In this kind of situation, major powers will be the most important actors in the systems while the weaker actors will follow the behaviaour of the major power.[8] Under this circumstances, cooperation is assumed to be difficult. But, Mearsheimer argues that cooperation still can be developed where cooperation takes place in a competition at its core so that states will take advantage of other states[8]. In contrast of defensive realism, offensive realist will suggest that state needs to pursue power so therefore states should be offensive. Offensive realism will be most likely to suggest that states need to develop foreign policy in order to secure their 
survival. Cooperation according to offensive realism will be part of the states' ultimate goal to gain the absolute power as hegemony. Therefore, for offensive realism, states should project their attributes economically and military to gain the power, in other words, states should use all strategies for survival to shift the balance of power in their favour and to prevent other states from shifting against them.

The three perspectives offer a different view on cooperation, based on the 'realistic' pictures of the international relations, where cooperation and non-cooperation schemes are occuring frequently. To borrow Keohane's words, "cooperation then is not simply a situation without conflicts, but more as a process that involves the use of means to stimulate mutual adjustment".[5] Another critic for HST comes from Peet.[9] Peet argues that although HST currently dominates the field of contemporary political explanations of international trade operating within the theoretical context of political realism.[9] As Peet notes, the world trade has continued to grow, in contradiction to the theory's predictions, numerous ad hoc explanations have surfaced which offer an account for the rise in trade while attempting to bolster hegemonic stability theory.[9] Peet suggests that HST should include the domestic and international variables which are related to the practices of some democratic industrial states to continue to increase their influence in the world trade in spite of a decline in the hegemonic status of the United States.[9]

Some people argue that there is a structural change happens in East Asia today. For a long time, people believe that the U.S. and Japan are acting as a hegemonic power served in the region. But now, people may see the rising power of China both in economy and military, the growing nuclear threats from North Korea, the decline economy strength of Japan, the reluctant US under Trump administration. This situation has left South Korea and Taiwan at the most vulnerable position. Taiwan is argued to gain the most disadvantages from the security dillemma in the region. As Mearsheimer in his 2014 article in The National Interest, that we may 'say good bye to Taiwan', to add the relevance of HST in explaining situation of East Asia region.[10]

The above facts lead to an assumption that the US is no longer the leader or hegemon in East Asia. The US has lost its leadership position in the region's structure. But using HST as a lens we can see that there are no structural changes in East Asia. Although Trump is acting to take the US out from East Asia sphere and no longer willing to sacrifice herself as a hegemon in the world, the U.S. is still serving as a leader in East Asia. Japan is still having their economic power, South Korea, and Taiwan now are more likely seeking support from the US and Japan. And regarding China. although its growing economic and military power is clear, China is not acting as a hegemon who is willing to sacrifice her attributes to serve as a leader in the region. Therefore, even though North Korea is now acting unexpectedly with its nuclear, East Asia remains stable because there is one hegemonic actor who is able to maintain status-quo relations among actors in the region.

While Ikenberry points out that to study the interactions among actors in East Asia. Ikenberry argues that the old American hegemonic order will remain a critical component of East Asian order in the future.[11] The cooperation between the US and East Asian countries create comprehensive relations between the parties. The US maintains its role in security provider in the region. As Ikenberry notes, China may serve well in the economic dimension and China shows a close relationship to the US, but China still needs a long way to take over the US presence in East Asia particularly in strategic terms.[11] Related to the hegemony stability, Ikenberry mentions that "The dangers to today's liberal hegemonic order are twofold. One is the growing duality and disjunction between where the region sees its economic and security futures.[11] Economically, most East Asian countries increasingly 
expect their future economic relations to be tied to China. In terms of security, most of these countries continue to expect to rely on American alliance protection". Ikenberry emphasizes that the rise of China lead East Asia to have a more close security link to the US.[11] From here, we can see that the US still play as a significant major power in East Asia.

Beeson highlights that East Asia still cannot refuse the US influence in the region and at the same time the US also needs East Asia because the context of Asia Pacific is declining.[12] Moreover, the rise of China as economic competitor leaves the US to opt for a closer relationship to East Asia. According to Beeson, "In the multi-layered political architecture that is emerging across East Asia, intra-regional ties are likely to become an increasingly important, functionally necessary, and normatively preferable part of regional practise and identity, in a way the Asia-Pacific never has or could".[12][13]

The rise of China's power is indeed a significant nuance in East Asia. But it is not necessarily that the region is looking for a dependence scheme with China. As Ross notes, 'the region is becoming increasingly more economically dependent on China than on the United States. But the rise of Chinese military power is less uniform; China is balancing U.S. power, but in distinct theaters, rather than throughout the region".[14] In this context, China may offer an appealling economic performance, but China still cannot draw attention from countries such as Japan, South Korea and Taiwan in military strategic terms.

According to Liu, the HST remains applicable in the case of US security architecture in Northeast Asia because the traditional diplomatic allies still rely on US military presence in the region to deter aggression from potential belligerents.[2] Liu notes that China is still undergoing rapid economic development, internal stability remains an important factor in the maintenance of regional security. Liu suggests that the US is still the dominant actor to maintain the regional order in East Asia while China is may play in regional stability and remains a tough bet for other states in maintaining security.[2] Although, Yong and Pauly suggest that in China, especially in the International Political Economy scholarships, there is a shifting perception on the Chinese economic power against the US's power.[15]

To sum up, looking at East Asian regional structure in international relations realms, I argue that there is no significant change in the system. Indeed, that China is rising as an important player with its economic power. However, in terms of security and ideology, China has not yet replace the US as the hegemon. Looking at the very recent event, when the world has been patiently watching the talk between Donald Trump and Kim Jong Un in Singapore this year, it is obvious that the US still an important player in East Asia. China and North Korea do not show attitude to abandon the US. Moreover, the rest of East Asian coutries; Japan, South Korea and Taiwan are definitely still holding on the strong US influence in the region.

\section{REFERENCES}


[1] H. Snyder, "Literature review as a research methodology: An overview and guidelines," J. Bus. Res., vol. 104, no. July, pp. 333-339, 2019.

[2] Tony Tai-Ting Liu, "Hegemonic Stability and Northeast Asia: What Hegemon? What Stability?," Asia Assoc. Glob. Stud. 2011 Annu. Conf., vol. 2, no. 2, pp. 216-230, 2011.

[3] C. Kindleberger, The World in Depression 1929-1939. Berkeley, CA: University of California Press, 1973.

[4] R. Gilpin, The Political Economy of International Relations. Ithaca: Princeton University Press, 1987.

[5] R. Keohane, After Hegemony: Cooperation and Discord in the World Political Economy. New Jersey: Princeton University Press, 1984.

[6] M. C. Webb and S. D. Krasner, "Hegemonic Stability Theory: An empirical assessment," Rev. Int. Stud., vol. 15, pp. 183-198, 1989.

[7] S. Walt, The Origins of Alliances. Ithaca: Cornell University Press, 1987.

[8] J. Mearsheimer, The Tragedy of Great Power Politics. New York: Norton, 2001.

[9] C. Peet, "Declining hegemony and rising international trade : Moving beyond hegemonic stability theory," Int. Interact. Empir. Theor. Res. Int. Relations, no. March 2015, pp. 37-41, 2008.

[10] J. Mearsheimer, "Say Good Bye to Taiwan," The National Interest, 2014.

[11] G. J. Ikenberry, "American hegemony and East Asian order," Aust. J. Int. Aff., vol. 58, no. 3, pp. 353-367, 2004.

[12] M. Beeson, "American Hegemony and Regionalism: The Rise of East Asia and the End of the Asia-Pacific American Hegemony and Regionalism : The Rise of East Asia and the End of the Asia-Pacific," Geopolitics, vol. 11, no. 4, pp. 541-560, 2006.

[13] M. Beeson and A. Broome, "Hegemonic Instability and East Asia : Contradictions, Crises and US Power Hegemonic Instability and East Asia : Contradictions , Crises," Globalization, vol. 7, no. 4, pp. 507-523, 2010.

[14] R. S. Ross, "Balance of Power Politics and the Rise of China: Accommodation and Balancing in East Asia," Secur. Stud., vol. 15, no. 3, pp. 185-239.

[15] W. Yong and L. Pauly, "Chinese IPE debates on ( American ) hegemony Chinese IPE debates on (American ) hegemony," Rev. Int. Polit. Econ., vol. 20, no. 6, pp. 11651188, 2013. 